\title{
Correction to: Impact of COVID-19 on vocal cord mobility: a case series study
}

Sameh M. Zamzam ${ }^{1,2^{*}}$ and Rania Gamal Hanafy ${ }^{3}$

Corrected to: Egypt J Otolaryngol 37, 93 (2021)

https://doi.org/10.1186/s43163-021-00157-y

Following the publication of the original article [1], the authors identified errors in the affiliations of Dr. Sameh M. Zamzam.

The correct affiliation is given below:

1ENT Department, Faculty of Medicine, Cairo University, Cairo, Egypt

The original article [1] has been corrected.

\section{Author details}

${ }^{1}$ ENT Department, Faculty of Medicine, Cairo University, Cairo, Egypt. ${ }^{2}$ ENT Department, Kasr Alainy Hospital, Garden City, Cairo, Egypt. ${ }^{3}$ ENT Department, Railway Hospital, Ramsis, Cairo, Egypt.

Published online: 12 November 2021

\author{
Reference \\ 1. Zamzam SM, Hanafy RG (2021) Impact of COVID-19 on vocal cord mobil- \\ ity: a case series study. Egypt J Otolaryngol 37:93. https://doi.org/10. \\ 1186/s43163-021-00157-y
} original author(s) and the source, provide a link to the Creative Commons licence, and indicate if changes were made. The images or other third party material in this article are included in the article's Creative Commons licence, unless indicated otherwise in a credit line to the material. If material is not included in the article's Creative Commons licence and your intended use is not permitted by statutory regulation or exceeds the permitted use, you will need to obtain permission directly from the copyright holder. To view a copy of this licence, visit http://creativecommons.org/licenses/by/4.0/. 